\title{
Stem Cells and Physical Energies: Can We Really Drive Stem Cell Fate?
}

\author{
S. CRUCIANI ${ }^{1}$, G. GARRONI ${ }^{1}$, C. VENTURA ${ }^{2}$, A. DANANI ${ }^{3}$, A. NEČAS $^{4}$, M. MAIOLI ${ }^{1,2,5,6}$
}

${ }^{1}$ Department of Biomedical Sciences, University of Sassari, Sassari, Italy, ${ }^{2}$ Laboratory of Molecular Biology and Stem Cell Engineering, National Institute of Biostructures and Biosystems - Eldor Lab, Innovation Accelerator, Consiglio Nazionale delle Ricerche, Bologna, Italy, ${ }^{3}$ Dalle Molle Institute for Artificial Intelligence Studies (IDSIA), University of Applied Sciences and Arts of Southern Switzerland (SUPSI), University of Southern Switzerland (USI), Manno, Switzerland, ${ }^{4}$ Faculty of Veterinary Medicine, University of Veterinary and Pharmaceutical Sciences, Brno, Czech Republic, ${ }^{5}$ Institute of Genetic and Biomedical Research, National Research Council, Cagliari, Italy, ${ }^{6}$ Center for Developmental Biology and Reprogramming-CEDEBIOR, Department of Biomedical Sciences, University of Sassari, Sassari, Italy.

Received September 25, 2019

Accepted October 20, 2019

\section{Summary}

Adult stem cells are undifferentiated elements able to self-renew or differentiate to maintain tissue integrity. Within this context, stem cells are able to divide in a symmetric fashion, feature characterising all the somatic cells, or in an asymmetric way, which leads daughter cells to different fates. It is worth highlighting that cell polarity have a critical role in regulating stem cell asymmetric division and the proper control of cell division depends on different proteins involved in cell development, differentiation and maintenance of tissue homeostasis. Moreover, the interaction between cells and the extracellular matrix are crucial in influencing cell behavior, included in terms of mechanical properties as cytoskeleton plasticity and remodelling, and membrane tension. Finally, the activation of specific transcriptional program and epigenetic modifications contributes to cell fate determination, through modulation of cellular signalling cascades. It is well known that physical and mechanical stimuli are able to influence biological systems, and in this context, the effects of electromagnetic fields (EMFs) have already shown a considerable role, even though there is a lack of knowledge and much remains to be done around this topic. In this review, we summarize the historical background of EMFs applications and the main molecular mechanism involved in cellular remodelling, with particular attention to cytoskeleton elasticity and cell polarity, required for driving stem cell behavior.

\section{Key words}

Stem cells • Cell polarity • Epigenetic • Electromagnetic fields • Physical stimuli

\section{Corresponding author}

M. Maioli, Department of Biomedical Sciences, University of Sassari, Sassari, Italy. E-mail: mmaioli@uniss.it

\section{Historical background}

Since the ancient times, the idea of using electric currents and magnets for healing have intrigued humanity. In China, more than 2000 years ago, "magnetic stones" were advocated to correct health imbalances (Unschuld 2003). In 46 aC, Scribonius Largus, a roman physician, mentioned the use of torpedo fish for treatment of headaches and gout in his Compositiones Medicae (Bennett et al. 1986). In the last two centuries, with the development of the electromagnetic theory, there has been a surge increase in the interest to the interaction of electromagnetic fields (EMFs) and various life processes. Particularly into the 20th century, plenty of bio-effects of electric, magnetic, and electromagnetic fields on human beings, animals and cells have been described either in vitro or in vivo conditions (Berg 1997, Berg 1999, Hönes 
et al. 1998). EMFs have reportedly therapeutic potentials for a wide variety of diseases including musculoskeletal diseases, cancer treatment, neurological disorders, wounds (Yadollahpour and Rashidi 2014, Shahpari et al. 2012, Ottani et al. 1988, Kloth and Feedar 1988).

The most famous and controversial pioneers in this field are probably Georges Lakhovsky and Antoine Priore. In the 30's, Lakhovsky invented the Multiple Wave Oscillator, which he claimed would revitalize and strengthen the health of cells, using resonance effects produced by his device (Lakhovsky 1992). Priore built in the 50's a series of electromagnetic devices producing a strong magnetic field for the purpose of treating cancer and disease. He reported to have treated a number of animals with cancer with his last most important device funded by French government, but this device broke down before it could be applied to human patients (Graille 1984). But both encountered big difficulties with the traditional medical community and these devices disappeared, even if there are still revivals in different forms even nowadays.

Concerning the field of regeneration, the most famous scientist and absolute pioneer is surely Alexander Gurwitsch. In 1922, he discovered that living cells separated by quartz glass were able to communicate vitalcell information. Numerous experiments suggested that this information was transmitted by invisible light waves in a UV frequency spectrum passed by quartz and stopped by window glass. Gurwitsch coined the phrase "mitotic" wave since it was observed during enzymatic reactions and mitosis. He also determined that muscle tissue, cornea, blood and nerves are all transmitters of this special energy. His work is the first documented evidence of "biophotons," coherent light emitted by animal and plant cells intensively studied later by Fritz-Albert Popp, and became the basis for the design of later bioelectromagnetic therapy devices (Gurwitsch 1968, Popp et al. 2002). Other important contributions are due to H. Saxton Burr and F. Stuart Northrope, who studied the role of bioelectric signals in embryonic development and regeneration, assuming the existence in 1935 of a bioelectrical field that they called "L-field" (Burr and Northrop 1939).

Significant steps forward in this topic were made by Robert Becker. Becker was intrigued by the capacity of the salamander to regenerate a paw from bones, muscles or nerves. Therefore, he decided to study the electric potential around the wounds, finding very small currents $(2-3 \mu \mathrm{A})$, for some days first negative, and then positive. Blocking these currents stops the regeneration of the tissue. His theory about the observations is fascinating and revolutionary: after a fracture or a wound, two electric currents are produced by the organism. One is coming from the injured tissue (bone or muscle), the other comes from the nerves. Both together meet and build a sort of battery, a "living electrode". In this way, the organism makes his own diagnosis, like X Rays, and leads the regrowth. At this point an incredible phenomenon takes place: specialized cells like erythrocytes are able to de-differentiate. In other terms, they acquire again like in the embryonal state, the capability to transform in any kind of cell. This phenomenon is unfortunately not possible for mammals, because they do not possess enough nervous cells, mostly concentrated in the brain. In 1971, with an external electric current, Becker succeeds in obtaining the beginning of regeneration on a mice paw, but for unknown reasons, the process stops along the way (Becker 1972). Becker popularized these and other advances in our understanding of the role of electric and magnetic fields in healing and regeneration in two books, The Body Electric (Becker 1985) and Cross Currents (Becker 1990).

Today, Michael Levin and colleagues at Tufts University are probably the most important active research group continuing to forward the exploration of bioelectromagnetics and physiology. Their research focuses on the genetic and biophysical mechanisms that enable decision-making during the complex development of the embryo and of individual organs and harnessing these insights towards developing new solutions for regenerative medicine and cancer suppression. By demonstrating that patterns in the electrical activity of biological cells act as key regulators of a variety of critical processes such as embryogenesis, regeneration, tumorigenesis and metastatic transformation, and that electrical patterning plays key roles in regenerative processes such as limb regeneration in salamanders, eye induction, craniofacial patterning, and head-tail polarity in planaria, Levin has shown that patterns of bioelectric signaling constitute "...an autonomous layer of control not reducible to a biochemical or genetic account of cell state" (Levin 2014).

\section{Cell polarity}

Adult stem cells from different tissues are known for self-renewing and for their capability to 
interact with their niche, maintaining a quiescent state, or undergoing differentiation toward a specific phenotype (Voog and Jones 2010). Mesenchymal stem cells can be isolated from different tissue, as bone marrow (Gnecchi and Melo 2009), adipose tissue (Araña et al. 2013), umbilical cord (Balzano et al. 2019), dental pulp (Ranganathan and Lakshminarayanan 2012). Stem cell fate can be modulated by chemical and physical intracellular or extracellular stimuli, that act through activation or repression of specific molecular pattern controlling cell proliferation and/or differentiation (Cruciani et al. 2019). Cell polarity is a fundamental property of migrating cells, and is related to the membrane organization and cytoskeleton arrangement that occur in response to different kind of signals (Goehring and Grill 2013, Cheng and Zygourakis 2007). Polarization and the capability to redistribute their cellular organelles and proteins, is essential for stem cell division and migration or adhesion to extracellular matrix (ECM) (Florian and Geiger 2010). In stem cells, the balance between symmetric and asymmetric division is aimed at regulating cell viability, proliferation and tissue homeostasis, and is perfectly controlled during the entire organism life (Egger et al. 2011, Wignall 2015). Asymmetric division results in two different daughter cells, one of which maintains the same self-renewal features of the mother cell and the other one with a reduced regenerative potential, that undergo differentiation toward a specific cell type (Murke et al. 2015). Dysregulation in this system leads to loss of tissue function or to uncontrolled cell proliferation, responsible for cancer initiation and progression (Muthuswamy and Xue 2012, Gómez-López et al. 2014). Moreover, stem cells lose their regenerative potential, dividing mainly in a symmetrical manner during their life (Jung and Brack 2014). Aging of hematopoietic stem cells (HSCs), as well as of mesenchymal stem cells from different tissues, is associated with loss of polarity and Wnt pathway dysregulation. This pathway is involved in hematopoiesis, thus its proper activation is important for homeostasis maintenance (Schultz and Sinclair 2016). Some authors demonstrated that a single-daughter cell transplant in mouse with aged HSCs, results in restoring asymmetric divisions and in rejuvenating their daughter stem cells (Florian et al. 2018). Endogenous electrochemical signals, as ion fluxes or membrane potential gradients, exert a key role in the activation of specific ion transporters and in regulating cell polarity during wound healing and regeneration processes
(Campetelli et al. 2012, Ikehara et al. 1998, Goudarzi et al. 2010). Membrane potential is dynamically regulated in order to guide import and export of anions and cations through the membrane, modulating the composition of extra-cellular liquids (Levin 2012). Recent studies on electric field responses in biological systems provided the ability of exogenous electric fields (EFs) to orient cell polarity, migration and division, also affecting the behavior during tissue regeneration (Chang and Minc 2014, Funk et al. 2009, Zhang et al. 2013, Pesce et al. 2013). For example, the Radio Electric Asymmetric Conveyer (REAC) technology, delivering radioelectric fields of $2.4 \mathrm{GHz}$, is able to optimize ions fluxes and drive cellular asymmetry and polarization, directly interacting with intrinsic cell electric field (Maioli et al. 2016b). Moreover, it has been demonstrated that embryonic stem cells stimulation by REAC, was able to exert a biphasic effect, optimizing the expression of pluripotency-related genes, or implementing stem cell differentiation potential without the use of chemical agents (Maioli et al. 2012). The same technology was able to act on human induced pluripotent stem cell (iPS) obtained from urine, increasing the achievement of a cardiogenic phenotype (Basoli et al. 2019). Within this context other studies revealed that iPS stimulation with EFs, exhibited an increase in cell migration and expression of pluripotent markers, unravelling a novel technique to facilitate stem cell therapy and migration of transplanted stem cells (Zhang et al. 2011).

\section{Cytoskeleton and membranes}

Cytoskeleton is a complex dynamic structure inside the cytoplasm of cells, which is responsible for cell movements, giving them the capability to resist to deformation, mediating signal transduction from ECM (Fletcher and Mullins 2010). Cytoskeleton rearrange its structure, according to environmental physical and chemical stimuli, through polymerization cycles of actin structures (Stricker et al. 2010). In stem cell biology, cytoskeleton exerts a central role in differentiation processes, plasticity, mechanotransduction and niche activities (Vining and Mooney 2017). In response to signals received from their microenvironment, unspecialized stem cells start to differentiate into mature specialized cell, involving cytoskeletal reorganization, fiber formation, expression of adhesion molecules and cell division (Ambriz et al. 2018). Several signaling and adhesion molecules connect the cytoskeleton with the 
ECM, thus being involved in membrane mechanotrasduction (Schwartz and DeSimone 2008). Among these Members of the mitogen-activated protein kinase (MAPK) family, extracellular signal-regulated kinase (ERK), integrins, selectins, and laminin receptors can be identified (Liu and Lee 2014). Variation in cytoskeletal structures, microtubules and actin filaments, lead to functional changes, altering intracellular signaling cascade, as during cellular senescence, leading to a different expression of Cyclin-dependent kinase inhibitors p16 and p21 (Moujaber et al. 2019, HernandezSegura et al. 2019). Aged cells show loss of proliferation and migration, along with a reduced regenerative potential (Rao and Cohen 1990). Some authors demonstrated that the application of repeated electromagnetic field shock (REMFS) on aged $\mathrm{T}$ lymphocytes and fibroblast cell lines, exerts an antiaging effect promoting Hsp90 release from the heat shock transcription factor (HSF1), inducing an increase in the number of proliferating cells (Perez et al. 2008a). The activation of cellular responses and repairing systems, mediated by REMFS-induced HSF1, could represent an important approach for managing Alzheimer and other age-related diseases (Perez et al. 2019, Perez et al. 2008b). Within this context, the exposure to electromagnetic fields induce a constant modulation of neural system, improving learning and memory impairment by stimulating neurogenesis in mice (Sakhaie et al. 2017, Leone et al. 2014), and implementing the achievement of a neurogenic phenotype in PC12 cell dopaminergic model (Maioli et al. 2015). When exposed to REAC technology, human adipose-derived stem cells (ADSCs) exposed to prolonged culturing senescence, showed a significant downregulation in the expression of senescence-associated genes (p16INK4, p53, p19) and $\beta$-galactosidase (Maioli et al. 2014a, Rinaldi et al. 2012). The anti-aging effect of REAC was mediated by the transcription of the catalytic telomerase subunit (TERT) and pluripotency-related genes. (Rinaldi et al. 2014), thus preserving cell commitment to different phenotypes.

\section{Influence on genes and epigenetics}

In vitro stem cell differentiation can be induced by chemical stimuli, such as small molecules that act modifying self-renewal, inducing cell differentiation and reprogramming (Ding and Schultz 2004, Li et al. 2013, Mansour et al. 2012, Mattout et al. 2011). Stem cell fate is controlled by multiple signaling pathways, involving
miRNAs (Gangaraju and Lin 2009, Balzano et al.2018), and other epigenetic events, such as DNA methylation and chromatin remodeling, still not completely yet understood (Lacagnina 2019, Bhuvanalakshmi et al. 2017, He et al. 2019). Growth factors, hormones, cytokines and other pharmacological agents can be added to the culturing medium to influence stem cell commitment toward specific phenotype (Christ et al. 2013, Maioli et al. 2016a). In particular molecules as melatonin and vitamin $\mathrm{D}$ are able to influence adipogenic and osteogenic differentiation processes in ADSCs cultured in specific conditioned media, by activating a specific epigenetic program and regulating gene expression (Basoli et al. 2017, Santaniello et al. 2018). Bone Morphogenetic Protein 9 (BMP-9) is able to induce osteogenic differentiation in mesenchymal stem cell by interacting with Wnt and IGF signaling pathways (Luther et al. 2011). Synthetic variant of pyrrolopyrimidine TWS119 is able to induce neurogenesis in embryonic stem cells by modulating serine/threonine kinase GSK-3 $\beta$ functions (Ding et al. 2003). Physical stimuli, as low frequency electromagnetic fields (ELFEFs) have been recently applied in the area of stem cells in the attempt to optimize cell growth and differentiation (Maioli et al. 2013a), without the need of chemical agents (Ross et al. 2015). Stem cells exhibit different responses to EFs depending on their differentiation status, by modulation of transcription factors and of genes involved in cell cycle regulation (Belyaev et al. 2005, Sun et al. 2009, Liu et al. 2015). REAC technology was able to induce the commitment of ADSCs toward neuronal, skeletal muscle and cardiac phenotypes, as well as a direct reprogramming of human fibroblasts toward the same lineages, creating an ideal environment for cell differentiation to be used in regenerative medicine (Maioli et al. 2014b, Maioli et al. 2013b). EFs has a stimulatory effect on osteoblasts mineralization, associated with an enrichment in cellular differentiation and bone tissue-like formation (Diniz et al. 2002, Kang et al. 2013). MSCs exposed to ELFEFs exhibited an increase in the expression of neurogenic markers, in the yield of the neuronal (Cho et al. 2012, Meng et al. 2009) and astrocyte differentiation by modulating SIRT1 expression (Jeong et al. 2017). ELFEFs mechanism of action involves mainly an increase in cytosolic $\mathrm{Ca}^{2+}$ concentration and the activation of $\mathrm{Ca}^{2+}$-binding proteins, leading to DNA methylation and histone posttranscriptional modifications in neurogenesis and osteogenesis processes (Leone et al. 2015). Moreover, the 
increased calcium concentration due to magnetic fieldmediated activation of voltage-gated calcium channels, promotes MSCs migration in injured sites, representing a valid way to increase the MSCs engraftment in clinical applications (Zhang et al. 2018).

\section{Physical energies and biological systems}

Several studies demonstrated the success of magnetic fields in driving stem cell commitment towards different phenotypes, and the chance to enroll the derived differentiated elements in clinical practice (Facchin et al. 2018). The interaction between EFs and biological systems generate responses at cellular and tissue levels, encompassing activation of specific molecular programs (Funk et al. 2006). In particular, considering its role in physiological regulation and in the organism response to the environment, nervous system represents a topic of interest for many researchers (Ramsay and Woods 2014). It has been previously demonstrated that ELFEFs improve neurogenesis and hippocampus-dependent memory in mice (Mastrodonato et al. 2018). In addition, they are able to induce proliferation and inhibit NSCs apoptosis, showing high potential in treatment of degenerative and psychiatric disease, as Parkinson, obsessive-compulsive disorder, epilepsy and other more (Cui et al. 2017, Mazzini et al. 2018). Nevertheless, EFs, being able to induce chondrogenic differentiation of progenitor cells and regeneration of articular cartilages can be also a valuable tool for in vivo management of musculoskeletal system, osteoarthritis, and chondral damages (Collodel et al. 2013, Sanna Passino et al. 2017, Hiraki et al. 1987). Physical stimuli find application also in cardiac-related diseases. Actually in vivo studies, both in mice and in humans, demonstrated that exposure of injured heart to EFs protects myocardium from the damages induced by oxidative stress, preserving metabolic activity in cardiomyocytes (Biały et al. 2018,
Ma et al. 2013). Finally, although the mechanism of action is not completely understood yet, clinical studies in humans revealed that magnetic fields can be successfully applied, together with conventional therapies, for rheumatic diseases, anxiety, depression and pain care (Hattapoğlu et al. 2019, Zwolińska et al. 2016).

\section{Conclusion}

Stem cells represent an important resource for regenerative medicine and tissue repairing. Nowadays, many clinical trials involving stem cell transplantation for regeneration of functional organs are taking place, thanks to stem cell immunomodulatory activity and their capability to migrate toward injured tissues. EFs application could have an important role in regulating biological responses to the environment, by direct modulating stem cells fate in their own niche, or improving human intrinsic biological self-healing capability, without the need of cell transplantation.

\section{Conflict of Interest}

There is no conflict of interest.

\section{Acknowledgments}

This work was supported by funds of institutional research (TA 29) FVM UVPS Brno and EU COST Project BIONECA action CA1622.

\begin{abstract}
Abbreviations
EMFs, electromagnetic fields; ECM, extracellular matrix HSCs, hematopoietic stem cells; EFs, electric fields; REAC, Radio Electric Asymmetric Conveyer; iPS, induced pluripotent stem cell; REMFS, repeated electromagnetic field shock; ADSCs, adipose-derived stem cells; ELFEFs, low frequency electromagnetic fields MSCs, mesenchymal stem cells; NSCs, neural stem cells.
\end{abstract}

\section{References}

AMBRIZ X, DE LANEROLLE P, AMBROSIO JR: The mechanobiology of the actin cytoskeleton in stem cells during differentiation and interaction with biomaterials. Stem Cells Int 2018: 2891957, 2018.

ARAÑA M, MAZO M, ARANDA P, PELACHO B, PROSPER F: Adipose tissue-derived mesenchymal stem cells: Isolation, expansion, characterization. Methods Mol Biol 1036: 47-61, 2013.

BALZANO F, BELLU E, BASOLI V, DEI GIUDICI S, SANTANIELLO S, CRUCIANI S, FACCHIN F, OGGIANO A, CAPOBIANCO G, DESSOLE F, VENTURA C, DESSOLE S, MAIOLI M: Lessons from human umbilical cord: gender differences in stem cells from Wharton's jelly. Eur J Obstet Gynecol Reprod Biol 234: 143-148, 2019. 
BALZANO F, CRUCIANI S, BASOLI V, SANTANIELLO S, FACCHIN F, VENTURA C, MAIOLI M: MiR200 and MiR302: Two big families influencing stem cell behavior. Molecules 23: 282, 2018. doi: 10.3390/molecules23020282.

BASOLI V, SANTANIELLO S, CRUCIANI S, GINESU GC, COSSU ML, DELITALA AP, SERRA PA, VENTURA C, MAIOLI M: Melatonin and vitamin D interfere with the adipogenic fate of adipose-derived stem cells. Int $J$ Mol Sci 18: pii: E981, 2017.

BASOLI V SANTANIELLO S, RINALDI S, FONTANI V, PIGLIARU G, WIESER M, STRAJERIU A, CASTAGNA A, REDL H, VENTURA C, GRILLARI R, MAIOLI M: Physical stimulation by REAC and BMP4/WNT-1 inhibitor synergistically enhance cardiogenic commitment in iPSCs. PLoS One 14: e0211188, 2019.

BECKER RO: Stimulation of partial limb regeneration in rats. Nature: 235: 109-111, 1972.

BECKER RO: Cross Currents, TarcherPerigee 1990.

BECKER RO, SELDEN G: The Body Electric: Electromagnetism and the Foundation of Life. W MORROW (ed), New York, 1985.

BELYAEV IY, HILLERT L, PROTOPOPOVA M, TAMM C, MALMGREN LO, PERSSON BR, SELIVANOVA G, HARMS-RINGDAHL M: $915 \mathrm{MHz}$ microwaves and $50 \mathrm{~Hz}$ magnetic field affect chromatin conformation and 53BP1 foci in human lymphocytes from hypersensitive and healthy persons. Bioelectromagnetics 26: 173-184, 2005.

BENNETT MVL, OBARA S: Ionic mechanisms and pharmacology of electroreceptors. In: Electroreception, TH BULLOCK, W HEILIGENBERG (eds), John Wiley, New York, 1986, pp 157-181.

BERG H: Elektrostimulation in der Zellbiologie. Stuttgart/Leipzig, 1997.

BERG H: Problems of weak electromagnetic field effects in cell biology. Bioelectrochem Bioenerg 48: 355-360, 1999.

BHUVANALAKSHMI G, ARFUSO F, KUMAR AP, DHARMARAJAN A, WARRIER S: Epigenetic reprogramming converts human Wharton's jelly mesenchymal stem cells into functional cardiomyocytes by differential regulation of Wnt mediators. Stem Cell Res Ther 8: 185, 2017.

BIAŁY D, WAWRZYŃSKA M, BIL-LULA I, KRZYWONOS-ZAWADZKA A, SAPA-WOJCIECHOWSKA A, ARKOWSKI J, WOŹNIAK M, SAWICKI G: Low frequency electromagnetic field decreases ischemiareperfusion injury of human cardiomyocytes and supports their metabolic function. Exp Biol Med (Maywood) 243: 809-816, 2018.

BURR HS, NORTHROP FSC: Evidence for the existence of an electro-dynamic field in living organisms. Proc Natl Acad Sci USA 25: 284-288, 1939.

CAMPETELLI A, BONAZZI D, MINC N: Electrochemical regulation of cell polarity and the cytoskeleton. Cytoskeleton (Hoboken) 69: 601-612, 2012.

CHANG F, MINC N: Electrochemical control of cell and tissue polarity. Annu Rev Cell Dev Biol 30: 317-336, 2014.

CHENG G, ZYGOURAKIS K: Cell migration. In: Tissue Engineering, JP FISHER, AG MIKOS, JD BRONZINO (eds), Taylor \& Francis, 2007.

CHO H, SEO YK, YOON HH, KIM SC, KIM SM, SONG KY, PARK JK: Neural stimulation on human bone marrowderived mesenchymal stem cells by extremely low frequency electromagnetic fields. Biotechnol Prog 28 : 1329-1335, 2012.

CHRIST GJ, SAUL JM, FURTH ME, ANDERSSON KE: The pharmacology of regenerative medicine. Pharmacol Rev 65: 1091-1133, 2013.

COLLODEL G, FIORAVANTI A, PASCARELLI NA, LAMBOGLIA A, FONTANI V, MAIOLI M, SANTANIELLO S, PIGLIARU G, CASTAGNA A, MORETTI E, IACOPONI F, RINALDI S, VENTURA C: Effects of regenerative radioelectric asymmetric conveyer treatment on human normal and osteoarthritic chondrocytes exposed to IL-1 $\beta$. A biochemical and morphological study. Clin Interv Aging 8: 309-316, 2013.

CRUCIANI S, SANTANIELLO S, MONTELLA A, VENTURA C, MAIOLI M: Orchestrating stem cell fate: Novel tools for regenerative medicine. World J Stem Cells 11: 464-475, 2019.

CUI M, GE H, ZHAO H, ZOU Y, CHEN Y, FENG H: Electromagnetic fields for the regulation of neural stem cells. Stem Cells Int 2017: 9898439, 2017.

DING S, SCHULTZ PG: A role for chemistry in stem cell biology. Nat Biotechnol 22: 833-840, 2004. 
DING S, WU TY, BRINKER A, PETERS EC, HUR W, GRAY NS, SCHULTZ PG: Synthetic small molecules that control stem cell fate. Proc Natl Acad Sci USA 100: 7632-7637. 2003.

DINIZ P, SHOMURA K, SOEJIMA K, ITO G: Effects of pulsed electromagnetic field (PEMF) stimulation on bone tissue like formation are dependent on the maturation stages of the osteoblasts. Bioelectromagnetics 23: 398-405, 2002.

EGGER B, GOLD KS, BRAND AH: Regulating the balance between symmetric and asymmetric stem cell division in the developing brain. Fly (Austin) 5: 237-241, 2011.

FACCHIN F, BIANCONI E, CANAIDER S, BASOLI V, BIAVA PM, VENTURA C: Tissue regeneration without stem cell transplantation: Self- healing potential from ancestral chemistry and physical energies. Stem Cells Int 2018: 7412035, 2018.

FLETCHER DA, MULLINS RD: Cell mechanics and the cytoskeleton. Nature 463: 485-492, 2010.

FLORIAN MC, GEIGER H: Concise review: Polarity in stem cells, disease, and aging. Stem Cells 28: 1623-1629, 2010.

FLORIAN MC, KLOSE M, SACMA M, JABLANOVIC J, KNUDSON L, NATTAMAI KJ, MARKA G, VOLLMER A, SOLLER K, SAKK V, CABEZAS-WALLSCHEID N, ZHENG Y, MULAW MA, GLAUCHE I, GEIGER H: Aging alters the epigenetic asymmetry of HSC division. PLoS Biol 16: e20033892018, 2018.

FUNK RHW, MONSEES TK: Effects of electromagnetic fields on cells: Physiological and therapeutical approaches and molecular mechanisms of interaction. A review. Cells Tissues Organs 182: 59-78, 2006.

FUNK RHW, MONSEES T, ÖZKUCUR N: Electromagnetic effects - From cell biology to medicine. Prog Histochem Cytochem 43: 177-264, 2009.

GANGARAJU VK, LIN H: MicroRNAs: Key regulators of stem cells. Nat Rev Mol Cell Biol 10: 116-125, 2009.

GNECCHI M, MELO LG: Bone marrow-derived mesenchymal stem cells: Isolation, expansion, characterization, viral transduction, production of conditioned medium. Methods Mol Biol 482: 281-294, 2009.

GOEHRING NW, GRILL SW: Cell polarity: Mechanochemical patterning. Trends Cell Biol 23: 72-80, 2013.

GÓMEZ-LÓPEZ S, LERNER RG, PETRITSCH C: Asymmetric cell division of stem and progenitor cells during homeostasis and cancer. Cell Mol Life Sci 71: 575-597, 2014.

GOUDARZI I, HAJIZADEH S, SALMANI ME, ABRARI K: Pulsed electromagnetic fields accelerate wound healing in the skin of diabetic rats. Bioelectromagnetics 31: 318-323, 2010.

GRAILLE JM: Dossier Priore: Une nouvelle affaire Pasteur ? (in French) Denoël (ed.) 1984.

GURWITSCH AA: Problems of Mitogenetic Radiation as an Aspect of Molecular Biology. (in Riussian) Medicina, Leningrad, 1968.

HATTAPOĞLU E, BATMAZ İ, DİLEK B, KARAKOÇ M, EM S, ÇEVİK R: Efficiency of pulsed electromagnetic fields on pain, disability, anxiety, depression, quality of life in patients with cervical disc herniation: a randomized controlled study. Turk J Med Sci 49: 1095-1101, 2019.

HE J, FU X, ZHANG M, HE F, LI W, ABDUL MM, ZHOU J, SUN L, CHANG C, LI Y, LIU H, WU K, BABARINDE IA, ZHUANG Q, LOH YH, CHEN J, ESTEBAN MA, HUTCHINS AP: Transposable elements are regulated by context-specific patterns of chromatin marks in mouse embryonic stem cells. Nat Commun 10: 34, 2019.

HERNANDEZ-SEGURA A, RUBINGH R, DEMARIA M: Identification of stable senescence-associated reference genes. Aging Cell 18: e12911, 2019.

HIRAKI Y, ENDO N, TAKIGAWA M, ASADA A, TAKAHASHI H, SUZUKI F: Enhanced responsiveness to parathyroid hormone and induction of functional differentiation of cultured rabbit costal chondrocytes by a pulsed electromagnetic field. Biochim Biophys Acta 931: 94-100, 1987.

HÖNES I, POSPISCHIL A, BERG H: Electrostimulation of proliferation of the denitrifying bacterium Pseudomonas stutzeri. Bioelectrochem Bioenerg 44: 275-278, 1998.

IKEHARA T, YAMAGUCHI H, MIYAMOTO H: Effects of electromagnetic fields on membrane ion transport of cultured cells. J Med Invest 45: 47-56, 1998.

JEONG WY, KIM JB, KIM HJ, KIM CW: Extremely low-frequency electromagnetic field promotes astrocytic differentiation of human bone marrow mesenchymal stem cells by modulating SIRT1 expression. Biosci Biotechnol Biochem 81: 1356-1362, 2017. 
JUNG Y, BRACK AS: Cellular mechanisms of somatic stem cell aging. Curr Top Dev Biol 107: 405-438, 2014.

KANG KS, HONG JM, KANG JA, RHIE JW, JEONG YH, CHO DW: Regulation of osteogenic differentiation of human adipose-derived stem cells by controlling electromagnetic field conditions. Exp Mol Med 45: e6, 2013.

KLOTH LC, FEEDAR JA: Acceleration of wound healing with high voltage, monophasic, pulsed current. Phys Ther 68: 503-538, 1988.

LACAGNINA S: Epigenetics. Am J Lifestyle Med 13: 556-560, 2019.

LAKHOVSKY G: The Secret of Life: Electricity, Radiation and Your Body, 1988.

LEONE L, FUSCO S, MASTRODONATO A, PIACENTINI R, BARBATI SA, ZAFFINA S, PANI G, PODDA MV, GRASSI C: Epigenetic modulation of adult hippocampal neurogenesis by extremely low-frequency electromagnetic fields. Mol Neurobiol 49: 1472-1486, 2014.

LEONE L, PODDA MV, GRASSI C: Impact of electromagnetic fields on stem cells: Common mechanisms at the crossroad between adult neurogenesis and osteogenesis. Front Cell Neurosci 9: 228, 2015.

LEVIN M: Molecular bioelectricity in developmental biology: New tools and recent discoveries: Control of cell behavior and pattern formation by transmembrane potential gradients. Bioessays 34: 205-217, 2012.

LEVIN M: Endogenous bioelectrical networks store non-genetic patterning information during development and regeneration. J Physiol 592: 2295-2305. 2014.

LI W, LI K, WEI W, DING S: Chemical approaches to stem cell biology and therapeutics. Cell Stem Cell 13: 270-283, 2013.

LIU YS, LEE OK: In search of the pivot point of mechanotransduction: mechanosensing of stem cells. Cell Transplant 23: $1-11,2014$.

LIU Y, LIU WB, LIU KJ, AO L, CAO J, ZHONG JL, LIU JY: Extremely low-frequency electromagnetic fields affect the miRNA-mediated regulation of signaling pathways in the GC-2 cell line. PLoS One 10: e0139949, 2015.

LUTHER G, WAGNER ER, ZHU G, KANG Q, LUO Q, LAMPLOT J, BI Y, LUO X, LUO J, TEVEN C, SHI Q, KIM SH, GAO JL, HUANG E, YANG K, RAMES R, LIU X, LI M, HU N, LIU H, SU Y, CHEN L, HE BC, ZUO GW, DENG ZL, REID RR, LUU HH, HAYDON RC, HE TC: BMP-9 induced osteogenic differentiation of mesenchymal stem cells: molecular mechanism and therapeutic potential. Curr Gene Ther 11: 229-240, 2011.

MA S, ZHANG Z, YI F, WANG Y, ZHANG X, LI X, YUAN Y, CAO F: Protective effects of low-frequency magnetic fields on cardiomyocytes from ischemia reperfusion injury via ROS and NO/ONOO-. Oxid Med Cell Longev 2013: 529173, 2013.

MAIOLI M, RINALDI S, SANTANIELLO S, CASTAGNA A, PIGLIARU G, GUALINI S, FONTANI V, VENTURA $\mathrm{C}$ : Radiofrequency energy loop primes cardiac, neuronal, skeletal muscle differentiation in mouse embryonic stem cells: a new tool for improving tissue regeneration. Cell Transplant 21: 1225-1233, 2012.

MAIOLI M, RINALDI S, SANTANIELLO S, CASTAGNA A, PIGLIARU G, DELITALA A, LOTTI MARGOTTI M, BAGELLA L, FONTANI V, VENTURA C: Amniotic fluid stem cells morph into a cardiovascular lineage: analysis of a chemically induced cardiac and vascular commitment. Drug Des Devel Ther 7: 1063-1073, 2013a.

MAIOLI M, RINALDI S, SANTANIELLO S, CASTAGNA A, PIGLIARU G, GUALINI S, CAVALLINI C, FONTANI V, VENTURA C: Radio electric conveyed fields directly reprogram human dermal skin fibroblasts toward cardiac, neuronal, skeletal muscle-like lineages. Cell Transplant 22: 1227-1235, $2013 \mathrm{~b}$.

MAIOLI M, RINALDI S, SANTANIELLO S, CASTAGNA A, PIGLIARU G, DELITALA A, LOTTI MARGOTTI M, BAGELLA L, FONTANI V, VENTURA C: Anti-senescence efficacy of radio-electric asymmetric conveyer technology. Age (Dordr) 36: 9-20, 2014a.

MAIOLI M, RINALDI S, SANTANIELLO S, CASTAGNA A, PIGLIARU G, DELITALA A, BIANCHI F, TREMOLADA C, FONTANI V, VENTURA C: Radioelectric asymmetric conveyed fields and human adipose-derived stem cells obtained with a nonenzymatic method and device: a novel approach to multipotency. Cell Transplant 23: 1489-1500, 2014 b.

MAIOLI M, RINALDI S, MIGHELI R, PIGLIARU G, ROCCHITTA G, SANTANIELLO S, BASOLI V, CASTAGNA A, FONTANI V, VENTURA C, SERRA PA: Neurological morphofunctional differentiation induced by REAC technology in PC12. A neuro protective model for Parkinson's disease. Sci Rep 5: 10439, 2015. 
MAIOLI M, BASOLI V, SANTANIELLO S, CRUCIANI S, DELITALA AP, PINNA R, MILIA E, GRILLARIVOGLAUER R, FONTANI V, RINALDI S, MUGGIRONI R, PIGLIARU G, VENTURA C: Osteogenesis from dental pulp derived stem cells: a novel conditioned medium including melatonin within a mixture of hyaluronic, butyric, retinoic acids. Stem Cells Int 2016: 2056416, $2016 \mathrm{a}$.

MAIOLI M, RINALDI S, PIGLIARU G, SANTANIELLO S, BASOLI V, CASTAGNA A, FONTANI V, VENTURA $\mathrm{C}$ : REAC technology and hyaluron synthase 2, an interesting network to slow down stem cell senescence. Sci Rep 6: 28682, 2016 b.

MANSOUR AA, GAFNI O, WEINBERGER L, ZVIRAN A, AYYASH M, RAIS Y, KRUPALNIK V, ZERBIB M, AMANN-ZALCENSTEIN D, MAZA I, GEULA S, VIUKOV S, HOLTZMAN L, PRIBLUDA A, CANAANI E, HORN-SABAN S, AMIT I, NOVERSHTERN N, HANNA JH: The H3K27 demethylase Utx regulates somatic and germ cell epigenetic reprogramming. Nature 488: 409-413, 2012.

MASTRODONATO A, BARBATI SA, LEONE L, COLUSSI C, GIRONI K, RINAUDO M, PIACENTINI R, DENNY CA, GRASSI C: Olfactory memory is enhanced in mice exposed to extremely low-frequency electromagnetic fields via Wnt/ $\beta$-catenin dependent modulation of subventricular zone neurogenesis. Sci Rep 8: $262,2018$.

MATTOUT A, BIRAN A, MESHORER E: Global epigenetic changes during somatic cell reprogramming to iPS cells. J Mol Cell Biol 3: 341-350, 2011.

MAZZINI L, FERRARI D, ANDJUS PR, BUZANSKA L, CANTELLO R, DE MARCHI F, GELATI M, GINIATULLIN R, GLOVER JC, GRILLI M, KOZLOVA EN, MAIOLI M, MITREČIĆ D, PIVORIUNAS A, SANCHEZ-PERNAUTE R, SARNOWSKA A, VESCOVI AL; BIONECA COST ACTION WG NEUROLOGY: Advances in stem cell therapy for amyotrophic lateral sclerosis. Expert Opin Biol Ther 18: 865-881. 2018.

MENG D, XU T, GUO F, YIN W, PENG T: The effects of high-intensity pulsed electromagnetic field on proliferation and differentiation of neural stem cells of neonatal rats in vitro. J Huazhong Univ Sci Technol Med Sci 29: 732-736, 2009.

MOUJABER O, FISHBEIN F, OMRAN N, LIANG Y, COLMEGNA I, PRESLEY JF, STOCHAJ U: Cellular senescence is associated with reorganization of the microtubule cytoskeleton. Cell Mol Life Sci 76: 1169-1183, 2019.

MURKE F, DA CONCEIÇÃO CASTRO SV, GIEBEL B, GÖRGENS A: Concise review: Asymmetric cell divisions in stem cell biology. Symmetry 7: 2025-2037, 2015.

MUTHUSWAMY SK, XUE B: Cell polarity as a regulator of cancer cell behavior plasticity. Annu Rev Cell Dev Biol 28: 599-625, 2012.

OTTANI V, DE PASQUALE V, GOVONI P, FRANCHI M, RUGGERI A, ZANIOL P: Effects of pulsed extremely low-frequency magnetic fields on skin wounds in the rat. Bioelectromagnetics 9: 53-62, 1988.

PEREZ FP, ZHOU X, MORISAKI J, JURIVICH D: Electromagnetic field therapy delays cellular senescence and death by enhancement of the heat shock response. Exp Gerontol 43: 307-316, 2008.

PEREZ FP, ZHOU X, MORISAKI J, ILIE J, JAMES T, JURIVICH DA: Engineered repeated electromagnetic field shock therapy for cellular senescence and age-related diseases. Rejuvenation Res 11: 1049-1057, 2008.

PEREZ FP, MORISAKI JJ, BANDEIRA JP: The effects of repeated electromagnetic field stimulation in aging and health. In: The Science of Hormesis in Health and Longevity, Elsevier, 2019.

PESCE M, PATRUNO A, SPERANZA L, REALE M: Extremely low frequency electromagnetic field and wound healing: Implication of cytokines as biological mediators. Eur Cytokine Netw 24: 1-10, 2013.

POPP FA, CHANG JJ, HERZOG A, YAN Z, YAN Y: Evidence of non-classical (squeezed) light in biological systems. Phys Lett A 293: 98-102, 2002.

RAMSAY DS, WOODS SC: Clarifying the roles of homeostasis and allostasis in physiological regulation. Psychol Rev 121: $225-247,2014$.

RANGANATHAN K, LAKSHMINARAYANAN V: Stem cells of the dental pulp. Indian J Dent Res 23: $558,2012$.

RAO KMK, COHEN HJ: The role of the cytoskeleton in aging. Exp Gerontol 25: 7-22, 1990. 
RINALDI S, MAIOLI M, SANTANIELLO S, CASTAGNA A, PIGLIARU G, GUALINI S, MARGOTTI ML, CARTA A, FONTANI V, VENTURA C: Regenerative treatment using a radioelectric asymmetric conveyor as a novel tool in antiaging medicine: An in vitro beta-galactosidase study. Clin Interv Aging 7: 191-194, 2012.

RINALDI S, MAIOLI M, PIGLIARU G, CASTAGNA A, SANTANIELLO S, BASOLI V, FONTANI V, VENTURA C: Stem cell senescence. Effects of REAC technology on telomerase-independent and telomerase-dependent pathways. Sci Rep 4: 6373, 2014.

ROSS CL, SIRIWARDANE M, ALMEIDA-PORADA G, PORADA CD, BRINK P, CHRIST GJ, HARRISON BS: The effect of low-frequency electromagnetic field on human bone marrow stem/progenitor cell differentiation. Stem Cell Res 15: 96-108, 2015.

SAKHAIE MH, SOLEIMANI M, POURHEYDAR B, MAJD Z, ATEFIMANESH P, ASL SS, MEHDIZADEH M: Effects of extremely low-frequency electromagnetic fields on neurogenesis and cognitive behavior in an experimental model of hippocampal injury. Behav Neurol 2017: 9194261, 2017.

SANNA PASSINO E, ROCCA S, CAGGIU S, COLUMBANO N, CASTAGNA A, FONTANI V, RINALDI S: REAC regenerative treatment efficacy in experimental chondral lesions: a pilot study on ovine animal model. Clin Interv Aging 12: 1471-1479, 2017.

SANTANIELLO S, CRUCIANI S, BASOLI V, BALZANO F, BELLU E, GARRONI G, GINESU GC, COSSU ML, FACCHIN F, DELITALA AP, VENTURA C, MAIOLI M: Melatonin and vitamin D orchestrate adipose derived stem cell fate by modulating epigenetic regulatory genes. Int J Med Sci 15: 1631-1639, 2018.

SCHULTZ MB, SINCLAIR DA: When stem cells grow old: phenotypes and mechanisms of stem cell aging. Development 143: 3-14, 2016.

SCHWARTZ MA, DESIMONE DW: Cell adhesion receptors in mechanotransduction. Curr Opin Cell Biol 20: 551-556, 2008.

SHAHPARI M, MIRNAJAFI-ZADEH J, SEYED SM, YADOLLAHPOUR A: Effect of low-frequency electrical stimulation parameters on its anticonvulsant action during rapid perforant path kindling in rat. Epilepsy Res 99: 69-77, 2012.

STRICKER J, FALZONE T, GARDEL ML: Mechanics of the F-actin cytoskeleton. J Biomech 43: 9-14, 2010.

SUN LY, HSIEH DK, YU TC, CHIU HT, LU SF, LUO GH, KUO TK, LEE OK, CHIOU TW: Effect of pulsed electromagnetic field on the proliferation and differentiation potential of human bone marrow mesenchymal stem cells. Bioelectromagnetics 30:'251-260, 2009.

UNSCHULD PU: Huang Di Nei Jing Su Wen: Nature, Knowledge, Imagery in an Ancient Chinese Medical Text, 2003.

VINING KH, MOONEY DJ: Mechanical forces direct stem cell behaviour in development and regeneration. Nat Rev Mol Cell Biol 18: 728-742, 2017.

VOOG J, JONES DL: Stem cells and the niche: a dynamic duo. Cell Stem Cell 6: 103-115, 2010.

WIGNALL SM: Cell division: stem cells take the stage. Curr Biol 25: R376-R378, 2015.

YADOLLAHPOUR A, RASHIDI S: Therapeutic applications of electromagnetic fields in musculoskeletal disorders: A review of current techniques and mechanisms of action. Biomed Pharmacol J 7: 23-32, 2014.

ZHANG J, CALAFIORE M, ZENG Q, ZHANG X, HUANG Y, LI RA, DENG W, ZHAO M: Electrically guiding migration of human induced pluripotent stem cells. Stem Cell Rev Rep 7: 987-996, 2011.

ZHANG M, LI X, BAI L, UCHIDA K, BAI W, WU B, XU W, ZHU H, HUANG H: Effects of low frequency electromagnetic field on proliferation of human epidermal stem cells: An in vitro study. Bioelectromagnetics 34: 74-80, 2013.

ZHANG Y, YAN J, XU H, YANG Y, LI W, WU H, LIU C: Extremely low frequency electromagnetic fields promote mesenchymal stem cell migration by increasing intracellular $\mathrm{Ca}^{2+}$ and activating the FAK/Rho GTPases signaling pathways in vitro. Stem Cell Res Ther 9: 143, 2018.

ZWOLIŃSKA J, GĄSIOR M, ŚNIEZEK E, KWOLEK A: The use of magnetic fields in treatment of patients with rheumatoid arthritis. Review of the literature. Reumatologia 54: 201-206, 2016. 